\title{
ANALISIS KETEPATAN WAKTU PELAPORAN KEUANGAN PEMERINTAH PUSAT PADA KANTOR PELAYANAN PERBENDAHARAAN NEGARA (KPPN) MAKASSAR I
}

\author{
Nouvita Heban ${ }^{1}$, Mariati $\mathbf{M}^{2}$, Taufik Thahir $^{3}$ \\ Sekolah Tinggi Ilmu Ekonomi YPUP Makassar \\ e-mail: nouvita@gmail.com , mariatimuhammad29@gmail.com , taufikthahir@gmail.com
}

\begin{abstract}
ABSTRAK
Penelitian ini bertujuan untuk mengetahui dan menganalisis ketepatan waktu Pelaporan Keuangan Pemerintah Pusat. Penelitian dilakukan pada Kantor Pelayanan Perbendaharaan Negara (KPPN) Makassar I yang berlokasi dijalan Slamet Riyadi No. 5 Makassar, Provinsi Sulawesi Selatan. Jenis data yang digunakan dalam penelitian ini adalah data kualitatif dan sumber data yang digunakan dalam penelitian ini adalah data primer dan data sekunder. Penelitian ini menggunakan teknik analisis deskriptif kualitatif.

Hasil analisis dari penelitian ini adalah bahwa penyampaian laporan keuangan pemerintah pusat oleh KPPN Makassar I selalu tepat waktu, ketepatan waktu ditunjang oleh sumber daya manusia yang kompoten, teknologi informasi dan aspek tata laksana organisasi.
\end{abstract}

Kata Kunci: Ketepatan Waktu, Pelaporan Keuangan Pemerintah Pusat

\section{ABSTRACT}

This study aims to see and analyze the timeliness of Central Government Financial Reporting. The research was conducted at the Makassar State Treasury Service Office (KPPN), which is located on Slamet Riyadi street No. 5 Makassar, South Sulawesi. The type of data used in this research is qualitative data and the data sources used in this study are primary data and secondary data. This study uses a qualitative descriptive analysis technique.

The results of the analysis of this research are that the submission of central government financial reports by KPPN Makassar 1 is always on time, on time supported by competent human resources, information technology and aspects of organizational governance.

Keywords: timeliness, financial reporting of central government.

\section{PENDAHULUAN}

Perkembangan sektor publik di Indonesia didorong oleh masyarakat yang menuntut agar pengelolaan anggaran negara (APBN) lebih transparan, akuntabel, dan berbasis kinerja. Hal ini yang mendorong pemerintah untuk mereformasi pengelolaan keuangan negara. Karena laporan keuangan pemerintah merupakan komponen yang penting untuk dapat memberikan informasi kepada publik dalam pengambilan keputusan oleh pihak luar.

Pelaporan Keuangan Pemerintah Pusat merupakan serangkaian prosedur mulai dari pengumpulan data, pencatatan, pengikhtisaran sampai dengan pelaporan posisi keuangan, dan operasi keuangan pada Kementerian Keuangan selaku Bendahara Umum Negara. Laporan keuangan adalah bentuk pertanggungjawaban pemerintah atas pelaksanaan Anggaran Pendapatan dan Belanja Negara berupa laporan realisasi 
anggaran, neraca pemerintah, laporan arus kas, laporan operasional, laporan perubahan ekuitas, laporan perubahan Saldo Anggaran Lebih, dan Catatan atas Laporan Keuangan.

KPPN Makassar 1 sebagai KPPN percontohan merupakan bagian dari reformasi birokrasi di kementerian keuangan, khususnya Direktorat Jenderal Perbendaharaan yang berkomitmen untuk terus meningkatkan pelayanan publik sebagai usaha untuk mewujudkan tata kelola pemerintahan yang baik (good governance) berbasis teknologi informasi dan berdasarkan Standar Operating Procedures (SOP) dengan terus menerus berusaha meningkatkan pelayanan kepada mitra kerja dan aktif mencari inovasi baru dalam meningkatkan pelayanan menuju pelayanan prima. Sejak ditetapkan sebagai KPPN percontohan, KPPN Makassar 1 mendapatkan apresiasi yang cukup membanggakan menyangkut kecepatan, ketepatan, keakuratan, akuntable, transparansi dalam proses penyelesaian pekerjaan serta pelayanan tanpa biaya kepada mitra kerja.

KPPN sebagai instansi vertikal yang berada dibawah Direktorat Jenderal Perbendaharaan dan bertanggungjawab kepada Kantor Wilayah, mempunyai peran yang besar dalam pelayanan kepada masyarakat berupa pencairan dana APBN, penatausahaan penerimaan dan pengeluaran Negara dan menyusun Laporan Keuangan Pemerintah Pusat (LKPP) sebagai pertanggungjawaban APBN di wilayah kerjanya berdasarkan peraturan perundang-undangan yang berlaku.

Kualitas informasi dapat dipengaruhi oleh waktu penyajian. Laporan keuangan harus disajikan tepat waktu agar dapat digunakan sebagai dasar pengambilan keputusan ekonomi. Pelaporan keuangan tidak hanya memuat laporan keuangan namun juga caracara lain dalam mengkomunikasikan informasi yang berhubungan secara langsung maupun tidak langsung, harus mempunyai informasi yang diberikan oleh sistem akuntansi yaitu informasi mengenai sumber daya dan pelaporan keuangan secara tepat waktu.

Walaupun KKPN Makassar I sebagai KKPN percontohan dan telah mendapatkan apresiasi yang membanggakan, namun peneliti belum terlalu yakin akan hal itu, oleh karena di beberapa daerah atau provinsi KKPN masih ada yang belum tepat waktu dalam pelaporannya, oleh karena itu merasa tertarik untuk mengetahui apa betul KKPN Makassar I sudah seperi itu adanya.

Berdasarkan latar belakang yang ada, maka rumusan masalah dalam penelitian ini adalah: bagaimana Pelaporan Keuangan Pemerintah Pusat ditinjau dari ketepatan waktu oleh KPPN Makassar I?

Berdasarkan rumusan masalah, maka tujuan dari penelitian ini adalah : Untuk mengetahui analisis ketepatan waktu Pelaporan Keuangan Pemerintah Pusat pada KPPN Makassar I.

\section{METODE PENELITIAN}

Pelaksanaan penelitian ini dilakukan pada Kantor Pelayanan Perbendaharaan Negara (KPPN) Makassar I yang beralamat di Jalan Slamet Riyadi No.5 Makassar Provinsi Sulawesi Selatan.

Jenis dan sumber data yaitu data kualitatif dan data kuantitatif, dan sumber datanya yaitu data primer dan sekunder

Adapun metode pengumpulan data dalam penelitian adalah sebagai berikut :

1. Wawancara merupakan teknik pengumpulan data dalam metode survey yang menggunakan pertanyaan secara lisan kepada subyek penelitian. Teknik wawancara dapat dilakukan dengan dua cara, yaitu melalui tatap muka atau 
melalui telepon. Adapun yang diwawancarai yakni Kepala atau Pimpinan KPPN Makassar I, Kepala Bagian Pelaporan dan Bagian teknologi informasi serta Bagian Akuntansi.

2. Dokumen merupakan kajian dari bahan dokumenter yang tertulis bisa berupa buku teks, surat-surat, naskah, artikel, dan sejenisnya, bahkan juga dapat berasal dari pikiran seseorang yang tertuang di dalam buku atau naskah yang terpublikasikan.

Analisis data yang digunakan dalam penelitian ini adalah metode deskriptif kualitatif. Penelitian deskriptif kualitatif merupakan data yang dikumpulkan dalam bentuk kata-kata atau gambar daripada angka-angka. Data tersebut mencakup transkrip wawancara, catatan lapangan, fotografi, videotape, dokumen pribadi, memo, dan rekaman-rekaman resmi lainnya.

Langkah-langkah yang dilakukan untuk menganalisis jawaban atas persoalan dalam penelitian ini ialah, sebagai berikut (Sugiono, 2008):

1. Mengidentifikasi dan mendeskripsikan kondisi dan situai KPPN Makassar 1 dalam kegiatan akuntansi dan pelaporan keuangan pemerintah pusat yang berhubungan dengan SDM, komitmen organisasi dan penggunaan teknologi informasi.

2. Mengidentifikasi analisis ketepatan waktu pelaporan keuangan pemerintah pusat pada KPPN Makassar I.

3. Menarik kesimpulan dan memberikan saran atas penelitian ini.

\section{HASIL DAN PEMBAHASAN}

\section{Hasil Penelitian}

Situasi Dan Kondisi KPPN Makassar I Dalam Kegiatan Akuntansi Dan Pelaporan Keuangan Pemerintah Pusat

Salah satu tugas KPPN adalah menyusun Laporan Keuangan Pemerintah Pusat (LKPP) tingkat Kuasa Bendahara Umum Negara, LKPP disusun oleh seksi verifikasi dan akuntansi dengan mengkompilasi data baik dari seksi verifikasi dan akuntansi itu sendiri maupun data dari seksi bank dan giro pos dan seksi pencairan dana. Untuk menghasilkan LKPP yang berkualitas dan dapat diandalkan maka setiap satuan kerja diwajibkan setiap bulannya untuk melakukan rekonsiliasi data. Rekonsiliasi berpengaruh terhadap Laporan Keuangan Pemerintah Pusat (LKPP). Rekonsiliasi yang dilakukan secara sempurna dan tepat waktu, akan menghasilkan laporan keuangan yang tepat dan akurat

Perwujudan Pertanggungjawaban sebagaimana diatur dalam Peraturan Menteri Keuangan Nomor 210/PMK.05 yang menyatakan bahwa Unit Akuntansi Kuasa Bendahara Umum Negara Tingkat Daerah/KPPN yang selanjutnya disebut UAKBUNDaerah/KPPN adalah unit akuntansi Kuasa BUN yang melakukan kegiatan akuntansi dan pelaporan keuangan bendahara umum negara tingkat daerah/KPPN. Berikut kutipan hasil wawancara dengan Kepala Seksi Verifikasi dan Akuntansi KPPN Makassar I :

"Pelaporan LK UAKBUN -Daerah disampaikan ke Kantor Wilayah Direktorat Jenderal Perbendaharaan paling lambat tanggal 13 bulan berikutnya. Dalam hal tanggal 13 bertepatan dengan hari libur/diliburkan, disampaikan paling lambat pada hari kerja 
sebelumnya sehingga penyampaian pelaporan keuangan pada KPPN Makassar I tidak pernah mengalami keterlambatan."

KPPN Makassar I merupakan KPPN Percontohan dengan melayani 204 satuan kerja yang tersebar diantaranya Provinsi Sulawesi Selatan 65 satuan kerja, Kota Makassar 91 satuan kerja, Kabupaten Maros 14 satuan kerja, Kabupaten Pangkep 13 satuan kerja, Kabupaten Gowa 12 satuan kerja, Kabupaten Takalar 9 satuan kerja. Pelaksanaan pekerjaan sehari-hari (business process) didalam memberikan pelayanan kepada satuan kerja mitra kerja KPPN Makassar I sudah diatur dalam peraturan perundang-undangan yang berlaku sesuai dengan Standar Prosedur Operasi/Standar Operating Procedures (SOP) dilingkungan Instansi Vertikal Direktorat Jenderal Perbendaharaan Negara.

Berikut kutipan hasil wawancara dengan Kepala Seksi Verifikasi dan Akuntansi KPPN Makassar I :

"Pelaporan LKPP oleh KPPN Makassar I selalu dibuat secara tepat waktu sesuai dengan Undang-Undang yang berlaku dan Standar Operating Procedures (SOP) berdasarkan surat pemberitahuan dari kantor pusat Direktorat Jenderal Perbendaharaan."

Bagian Seksi Verikasi dan Akuntansi merupakan bagian yang terlibat langsung dalam penyusunan Pelaporan Keuangan Pemerintah Pusat. Pada bagian ini terdapat 4 orang pegawai yang bertugas untuk menyusun laporan keuangan. Dari 4 orang pegawai tersebut, terdapat 1 orang pegawai yang memiliki latar belakang pendidikan selain Akuntansi dan kurang memahami teknologi informasi. Berikut kutipan wawancara dengan Kepala KPPN Makassar I:

"Saat ini KPPN Makassar I sering mengadakan sosialisasi atau rapat koordinasi tentang Peraturan dan atau Program Aplikasi terbaru kepada para pegawai yang tidak memiliki latar belakang pendidikan sarjana ataupun Teknologi Informasi sehingga mereka dengan mudah bisa menjalankan pekerjaannya sesuai dengan tugas masing-masing."

Selain dukungan sumber daya manusia diatas Kantor Pelayanan Perbendaharaan Negara Makassar I didukung sarana dan prasarana yang memadai sesuai dengan standard yang telah ditetapkan oleh Ditjen Perbendaharaan dengan gedung Kantor Pelayanan Perbendaharaan Negara Makassar I menempati Gedung KPPN Makassar I di Jalan Slamet Riyadi No. 5 yang pengelolaanya dilaksanakan oleh KPPN Makassar I. Teknologi infomasi yang terdapat pada KPPN Makassar I sudah sangat memadai sehingga sangat mendukung kecepatan penyelesaian pekerjaan pegawai dan sangat menunjang keakuratan data. Sehingga dapat memberikan pelayanan yang baik dan lancar kepada 204 Satuan Kerja dilingkungan kerja KPPN Makassar I.

Bentuk Komunikasi dengan KPPN dari seluruh unit kerja Direktorat Jenderal Perbendaharaan (DJPBN) dilakukan secara online dengan menggunakan fasilitas website DJPBN sehingga apapun bentuk informasi yang disampaiakan akan dengan cepat dan mudah untuk diketahui. Adapun pertanyaan, kritikan ataupun saran yang diharapkan untuk membuat program kerja dapat dijalankan melalui website. Berikut kutipan hasil wawancara dengan salah satu pelaksana Seksi Verifikasi dan Akuntansi :

"Penyusunan dan penyampaian pelaporan keuangan pemerintah pusat dilengkapi dengan sarana aplikasi komputer yang di standarkan dari pusat. Aplikasi yang dioperasionalkan oleh KPPN Makassar I dalam proses rekonsiliasi untuk para satuan kerja yaitu Aplikasi Sistem Akuntansi Instansi (SAI). Adapun Aplikasi yang digunakan oleh seksi verifikasi dan akuntansi dalam proses penyusunan laporan keuangan menggunakan Aplikasi Sistem Perbendaharaan Anggaran Negara (SPAN) setelah 
laporannya selesai disusun akan dikirim ke pusat dalam bentuk file pdf dengan menggunakan email."

Sistem Perbendaharaan dan Anggaran Negara (SPAN) merupakan suatu sistem proses bisnis yang saling terhubung satu sama lain dalam satu jaringan dan database. Tujuannya sudah pasti adalah peningkatan kualitas pengelolaan keuangan negara, akurasi dan akuntabilitas data, serta kualitas laporan keuangan yang baik. SPAN sebagai suatu sistem berbasis teknologi informasi ditunjukan untuk mendukung pencapaian prinsip-prinsip pengelolaan anggaran tersebut. Seluruh proses yang terkait dengan pengelolaan anggaran yang meliputi penyusunan anggaran, manajemen pembayaran, manajemen kontrak, manajemen dokumen anggaran, manajemen supplier, manajemen kas serta proses akuntansi dan pelaporan diintegrasikan ke dalam SPAN.

Teknis Operasional penyelesaian pekerjaan di KPPN Makassar I didasarkan pada fungsi yaitu Front Office, Middle Office, dan Back Office. Front Office adalah unit/pegawai yang pertama kali berhubungan secara langsung dengan mitra kerja atau stakeholder. Middle Office adalah unit yang memproses lebih lanjut pekerjaan yang dilakukan Front Office dan tidak secara langsung berhubungan dengan mitra kerja atau stakeholder. Back Office adalah unit/pegawai yang merupakan muara terakhir penyelesaian pekerjaan di KPPN Makassar I (Percontohan) yang terkait dengan penyelesaian laporan yang bersifat accountability report.

\begin{tabular}{|c|c|c|c|c|}
\hline \multicolumn{5}{|c|}{ Pelaksanaan Waktu Pelaporan } \\
\hline No & Jenis Laporan & $\begin{array}{l}\text { Waktu Pembuatan } \\
\text { Laporan }\end{array}$ & $\begin{array}{c}\text { Waktu } \\
\text { Pelaksanaan } \\
\text { Pelaporan }\end{array}$ & $\begin{array}{c}\text { Batas Waktu } \\
\text { penyampaian } \\
\text { pelaporan }\end{array}$ \\
\hline 1 & $\begin{array}{l}\text { Laporan Keuangan Unit } \\
\text { Akuntansi Kuasa } \\
\text { Bendahara Umum Negara } \\
\text { (UAKBUN)-Daerah Tahun } \\
2015\end{array}$ & 28 Desember 2018 & 13 April 2019 & 14 April 2019 \\
\hline 2 & $\begin{array}{l}\text { Laporan Keuangan Unit } \\
\text { Akuntansi Kuasa } \\
\text { Bendahara Umum Negara } \\
\text { (UAKBUN)-Daerah Tahun } \\
2016\end{array}$ & 12 April 2019 & 18 April 2019 & 19 April 2019 \\
\hline 3 & $\begin{array}{l}\text { Laporan Keuangan Unit } \\
\text { Akuntansi Kuasa } \\
\text { Bendahara Umum Negara } \\
\text { (UAKBUN)-Daerah Tahun } \\
2017\end{array}$ & 2 April 2019 & 12 April 2019 & 13 April 2019 \\
\hline
\end{tabular}

Sumber : KPPN Makassar I

Laporan Keuangan Unit Akuntansi Kuasa Bendahara Umum Negara (UAKBUN)Daerah mulai Tahun 2018-2019 waktu pembuatan laporan berdasarkan surat pemberitahuan dari pusat untuk segara menyampaikan laporan keuangan tingkat KPPN Makassar I dengan batasan waktu yang telah ditentukan. Untuk itu pihak KPPN Makassar I menyusun dan menyampaikan laporan keuangannya sebelum batas waktu yang sudah ditentukan agar pelaporan keuangan tersebut selalu tepat waktu sesuai jadwal yang telah ditentukan.

\section{PEMBAHASAN}


Berdasarkan kondisi dan situasi diatas maka yang menjadi analisis ketepatan waktu penyampaian pelaporan keuangan pemerintah pusat oleh KPPN Makassar I yaitu, selalu tepat waktu, ketepatan waktu pelaporan keuangan ditunjang oleh :

1. Sumber Daya Manusia yang Kompeten

Sumber Daya Manusia memegang peranan strategis dalam menunjang keberhasilan pelayanan KPPN, oleh karena perekrutan SDM pada KPPN Makassar I dilakukan secara ketat, dengan mempertimbangkan aspek penguasaan teknis pekerjaan dan tes psikometrik untuk mengetahui aspek moralitas dan integritas pegawai. Hal ini mengingat bahwa untuk menunjang operasional KPPN Makassar I para pegawai yang telah diseleksi dapat menyelesaikan pekerjaan yang lebih sederhana serta dukungan teknologi informasi yang terintegrasi.

Kompetensi Sumber Daya Manusia yang ada di Bagian Seksi Verifikasi dan Akuntansi telah efektif dalam menjalankan tugas pembuatan dan pengiriman laporan keuangan pemerintah pusat sehingga penyampaian pelaporan keuangan pemerintah pusat oleh KPPN Makassar I selalu dilakukan secara tepat waktu. Pentingnya peranan pimpinan untuk selalu memperhatikan dan membina stafnya agar kinerjanya tetap baik dan disiplin.

2. Dukungan Teknologi Informasi

Pemanfaatan Teknologi Informasi perlu dioptimalkan untuk meningkatkan kecepatan dan keakuratan penyelesaian pekerjaan sehingga bisa mengurangi pekerjaan yang manual dan menyita waktu. Dari sisi transparansi, pemanfaatan teknologi informasi akan mempermudah pihak-pihak yang memiliki kepentingan dengan layanan oleh KPPN Makassar I untuk mengakses dan mengawasi proses penyelesaian pekerjaan.

Teknlogi Informasi yang digunakan oleh KPPN Makassar I berupa Komputer keluaran terbaru dan software jenis baru serta Aplikasi Sistem Perbendaharaan dan Anggaran Negara disingkat SPAN, aplikasi ini memberikan dukungan agar terciptanya akuntabilitas dan transparan dalam pengelolaan keuangan negara, serta memiliki kecepatan dalam memproses data keuangan dari para satuan kerja sehingga menjamin akurasi data dan kecepatan dalam memproses laporan keuangan yang laksanakan oleh Seksi Verifikasi dan Akuntansi sebagai penyusunan dan penyampaian laporan keuangan pemerintah pusat KPPN.

3. Tata Laksana Organisasi

Sumber daya manusia yang tersedia harus memenuhi syarat dari aspek moralitas dan kompetensi, selain itu juga perlu adanya prosedur kerja yang jelas dan mendetail, serta bisa dipertanggung jawabkan dan dijadikan sebagai pedoman bagi pegawai dalam melaksanakan tugas, maka disusunlah Standar Prosedur Operasi (SOP) setiap penyelesaian pekerjaan dengan mempertimbangkan aspek penyederhanaan prosedur dan transparansi dalam setiap penyelesaian pekerjaan.

KPPN Makassar I sebagai pelayanan publik yang unggulan di lingkungan Direktorat Jenderal Perbendaharaan yaitu Penyelesaian Surat Perintah Pencairan Dana (SP2D), Penatausahaan Penerimaan Negara melalui Modul Penerimaan Negara (MPN), dan pengelolaan Laporan Keuangan Pemerintah Pusat (LKPP) yang akurat dan tepat waktu.

\section{KESIMPULAN}

Penelitian ini bertujuan untuk mengetahui analisis ketepatan waktu pelaporan keuangan pemerintah pusat pada Kantor Pelayanan Perbendaharaan Negara (KPPN) 
Makassar I. Setelah melakukan analisis terhadap hasil dan pembahasan penelitian ini, maka dapat disimpulkan sebagai berikut :

1. Analisis ketepatan waktu pelaporan keuangan pemerintah pusat pada KPPN Makassar I adalah Sumber Daya Manusia yang kompeten, Dukungan Teknologi Informasi, serta Aspek Tata Laksana Organisasi.

2. Pelaporan keuangan yang dilakukan oleh KPPN Makassar I selalu tepat waktu sesuai dengan jadwal yang telah ditentukan

\section{SARAN}

Berdasarkan kesimpulan dalam penelitian ini, maka dapat dikemukakan beberapa saran, yaitu sebagai berikut:

1. Bagi pihak KPPN Makassar I, hendaknya memprioritaskan pelaporan keuangannya agar organisasi tersebut terhindar dari kesalahan/kegagalan dan penundaan waktu sehingga memenuhi kriteria yaitu cepat, tepat, akurat, dan akuntabel.

2. Bagi peneliti selanjutnya, sebaiknya menggunakan metode analisis data yang berbeda dan menggunakan variabel-variabel lain yang dirasa mungkin mempengaruhi ketepatan waktu pelaporan keuangan pemerintah pusat dengan tujuan apakah terdapat kesamaan faktor ataukah terdapat perbedaan faktor.

\section{UCAPAN TERIMA KASIH}

Dengan selesainya penelitian ini tidak lepas dari bantuan dari berbagai pihak terutama pimpinan Kantor Pelayanan Perbendaharaan Negara (KPPN) Makassar 1 beserta staff dan pimpinan STIE YPUP yang telah memberikan kesempatan dan biaya peneliatian oleh karena itu atas segala bantuannya kami menghaturkan banyak terima kasih.

\section{DAFTAR PUSTAKA}

Amiani, Astrid Patricia. 2014. Faktor-faktor yang Mempengaruhi Ketepatan Waktu Laporan Keuangan Pemerintah Pusat Pada KPPN Palangka Raya. Skripsi. Salatiga : Fakultas Ekonomika Dan Bisnis, Universitas Kristen Satya Wacana.

Emzir. 2016. Metodologi Penelitian Kualitatif : Analisis Data. Edisi I, Cetakan ke-5. PT.Raja Grafindo Persada. Jakarta.

Fauzan, M., dan Baharuddin Siagian. 2017. Perpustakaan Nasional: Katalog Dalam Terbitan (KDT). Cetakan ke-1. KENCANA. Depok.

Fauziah, Ifat. 2018. Standar Akuntansi Pemerintahan. Cetakan Pertama. Ilmu Media (Serambi). Jakarta.

Keputusan Direktur Jenderal Perbendaharaan Nomor KEP-239/PB/2015 tentang Rencana Strategis Direktorat Jenderal Perbendaharaan Tahun 2015-2019.

Mahsun, Moh., Firma Sulistiyowati, Heribertus Andre Purwanugraha. 2016. Akuntansi Sektor Publik. Edisi ke-3, Cetakan ke-6. BPFE. Yogyakarta.

Peraturan Menteri Keuangan Nomor 262/PMK.05/2014 tentang Sistem Akuntansi dan Pelaporan Keuangan Pemerintah Pusat.

Nomor 270/PMK.05/2014 tentang Penerapan Standar Akuntansi

Pemerintahan Berbasis Akrual Pada Pemerintah Pusat.

Pemerintah Nomor 71 Tahun 2010 tentang Standar Akuntansi Pemerintahan.

Prasadja, Ricardianto. 2018. Human Capital Management. IN MEDIA. Bogor. 
Rachim, Abd. 2015. Barometer Keuangan Negara/Daerah. Cv. Andi Offset. Edisi I. Yogyakarta.

Rachmawi, Sella., Rini, Yessi Fitri. 2016. Faktor-Faktor Yang Mempengaruhi Ketepatan Waktu Pelaporan Keuangan Pemerintah Daerah Di Indonesia. Jurnal Ilmu Akuntansi Volume 9 (I), April 2016. UIN Syarif Hidayatullah. Jakarta.

Renyowijoyo, Muindro. 2013. Akuntansi Sektor Publik Organisasi Non Laba. Mitra Wacana Media. Jakarta.

Robbins, Stephen. P., dan Mary Coulter. 2016. Manajemen. Edisi ke-13, Jilid 2. Penerbit Erlangga. Jakarta.

Sedarmayanti. 2017. Perencanaan dan Pengembangan Sumber Daya Manusia Untuk Meningkatkan Kompetensi Kinerja dan Produktivitas Kerja. PT. Refika Aditama. Bandung.

Sujarweni, Wiratna. V. 2014. Metodologi Penelitian. Cetakan Pertama. PUSTAKABARUPRESS. Yogyakarta.

http://www.kppnmakassar1.net 